\title{
Disparities in habitat use and migratory behavior between tropical eel Anguilla marmorata and temperate eel $A$. japonica in four Taiwanese rivers
}

\author{
J. C. Shiao ${ }^{1}$, Y. Iizuka ${ }^{2}$, C. W. Chang ${ }^{3}$, W. N. Tzeng ${ }^{3,4, *}$ \\ ${ }^{1}$ Institute of Zoology, and ${ }^{2}$ Institute of Earth Sciences, Academia Sinica, 128, Section 2, Academia Road, Nankang, Taipei, \\ Taiwan 115, ROC \\ ${ }^{3}$ Department of Zoology, National Taiwan University, 1, Section 4, Roosevelt Road, Taipei, Taiwan 106, ROC \\ ${ }^{4}$ Present address: Institute of Fisheries Sciences, National Taiwan University, Taipei, Taiwan 106, ROC
}

\begin{abstract}
Strontium (Sr):calcium (Ca) ratios in otoliths of the eels Anguilla japonica and A. marmorata caught in 4 Taiwanese rivers were examined to reconstruct their migratory environmental history. In all sampling locations, each eel species preferred a different environment and all were differently distributed in the river. A. japonica was more abundant than A. marmorata in the lower reach, accounting for 76 to $86 \%$ of the eel population. In contrast, A. marmorata was more abundant than A. japonica in the upper reach, accounting for 76 to $100 \%$ of the eel population. A. japonica consisted of diversified migratory contingents, including freshwater, brackish-water and seawater eels, but A. marmorata tended to reside in freshwater and seemed to avoid seawater during the yellow eel stage. This disparity in migratory behaviors and habitat use between species may reflect interspecific competition and adaptive radiation. The flexible migratory behavior and adaptation to different salinities of A. japonica may be an advantageous evolutional fitness when facing competition, heavy fishing pressure and environmental stress. The freshwater-restricted A. marmorata is more easily threatened by both fishing pressure and continuous habitat degradation than A. japonica.
\end{abstract}

KEY WORDS: Anguilla japonica $\cdot$ Anguilla marmorata $\cdot$ Otolith microchemistry $\cdot$ Environmental history $\cdot$ Migratory behaviors $\cdot$ Adaptive radiation

Resale or republication not permitted without written consent of the publisher

\section{INTRODUCTION}

There are 4 species of Anguilla eels in Taiwan. A. japonica is the most abundant, followed by $A$. marmorata. The other 2 tropical species, A. bicolor pacifica and A. celebesensis, are rare and only occasionally found in the estuaries of Taiwan (Tzeng 1982, 1983, Tzeng \& Tabeta 1983, Tzeng et al. 1994, Han et al. 2001). A. japonica is a temperate species, occurring from Taiwan through to Japan in NE Asia (Ege 1939, Tesch 1977). The eels spawn west of the Mariana Islands (Tsukamoto 1992). Their leaf-like leptocephalus larvae take ca. 4 to 5 mo to migrate with the North Equatorial and Kuroshio Currents, and metamorphose into transparent glass eels on the edge of the NE Asian continental shelf (Tzeng 1990, 2003, Tzeng \& Tsai 1994, Cheng \& Tzeng 1996). The glass eels become pigmented elvers in the estuaries and live in the river for approximately 5 to $8 \mathrm{yr}$, during which they develop from elvers to the yellow and silver eel stages. The sexually maturing silver eels migrate to the spawning ground, where they die after spawning.

Anguilla marmorata is widely distributed in NE Asia and the Indo-Pacific Ocean. It is an endangered species in Taiwan. Budimawan (1997) and Arai et al. $(2002 a, b)$ have reported its age at recruitment and seasonal occurrence in the estuaries of Japan, Taiwan and other Pacific countries. They may spawn west of the Mariana Islands, like A. japonica (Miller \& Tsukamoto 
2001). The species is relatively long-lived; a $17 \mathrm{yr}$ old female A. marmorata was found in the Pearl River of south China (Williamson 1993). Knowledge of this eel's life history is very limited.

Anguilla japonica and A. marmorata coexist in Taiwanese rivers, and may share the same niches, use the same demersal habitats and forage for the same prey (Tzeng et al. 1995). Thus, interspecific competition might play an important role in regulating their habitat use and population size. Mechanisms may exist to avoid interspecific competition and attain maximum benefit for each eel species in the river. Habitat segregation and behavior differentiation might be the effective means. Fishermen's experience has indicated that A. japonica is dominant in the lower reach of the river and estuary, while $A$. marmorata dominates in the middle to upper reaches of the river. However, in many small brooks of Taiwan, ecological niches are seriously compressed, so that there is no apparent boundary to distinguish lower reach from middle reach, or middle reach from upper reach. Consequently, the presumed segregative distribution of the 2 eel species in the rivers needs evaluation. Tzeng et al. (2002) found that A. japonica tended to stay in brackish waters in the rivers of Taiwan. The other temperate eels, A. anguilla in Europe, and A. rostrata in North America, also have a flexible migratory life cycle, i.e. a portion of the eel population might skip freshwater residence and live in estuarine and coastal waters until maturation (Tzeng et al. 1997, 2000a, Tsukamoto et al. 1998, Tsukamoto \& Arai 2001, Jessop et al. 2002). Whether the tropical eel A. marmorata has a similarly flexible migratory behavior or merely resides in freshwater, is still unclear and intriguing.

Fish otoliths are metabolically inert and grow by seasonal accretion throughout the life of the fish (Pannella 1971). Strontium (Sr) can substitute for calcium (Ca) in the process of otolith deposition, because it has a similar ionic charge and radius to Ca (Payan et al. 1999). The concentration of $\mathrm{Sr}$ is approximately 100-fold greater in seawater $\left(8.7 \times 10^{-5} \mathrm{M}\right)$ than freshwater $(9 \times$ $10^{-7} \mathrm{M}$ ) (Campana 1999) and the Sr:Ca ratios in fish otoliths are higher in marine and brackish waters than in freshwater (Tzeng 1996a). Thus, otolith Sr:Ca ratios are extensively used to study the migratory environmental history of diadromous fishes (Radtke et al. 1988, 1990), including freshwater eels (Otake et al. 1994, Tzeng \& Tsai 1994, Arai et al. 1997, 1999, Tzeng et al. 1997, 2000a, Kawakami et al. 1998, Jessop et al. 2002).

The aim of this study is to (1) reconstruct the migratory environmental history of Anguilla marmorata and A. japonica in Taiwanese rivers by examining otolith $\mathrm{Sr}: \mathrm{Ca}$ ratios using an electron probe microanalyzer (EPMA) and to determine their age by examining otolith annuli, (2) examine the adaptive distribution of A. japonica and A. marmorata in the rivers, and (3) compare the distribution and migratory environment of these 2 species, to improve understanding of the species-specific habitat use and migratory behavior of anguillid eels.

\section{MATERIALS AND METHODS}

Fish collection and sampling area. Anguilla japonica and A. marmorata of yellow and silver eel stages were collected with a bamboo eel pot (Fig. 1). The pot was approx. $100 \mathrm{~cm}$ long and 10 to $15 \mathrm{~cm}$ in diameter, and an earthworm was placed inside as bait. The eel pot was set on the river bottom, with the entrance facing downstream, and was retrieved the following morning to check the catch. Each eel collected was measured to the nearest $5 \mathrm{~mm}$ in total length and dissected to determine its sex by gonadal histology (Han et al. 2001). The developmental stage of each eel was determined by its morphological characteristics, e.g. size, color, diameter of eyes and degree of sexual maturation. The specimens used for otolith $\mathrm{Sr}: \mathrm{Ca}$ ratio analysis and age determination from each location and species are listed in Table 1.

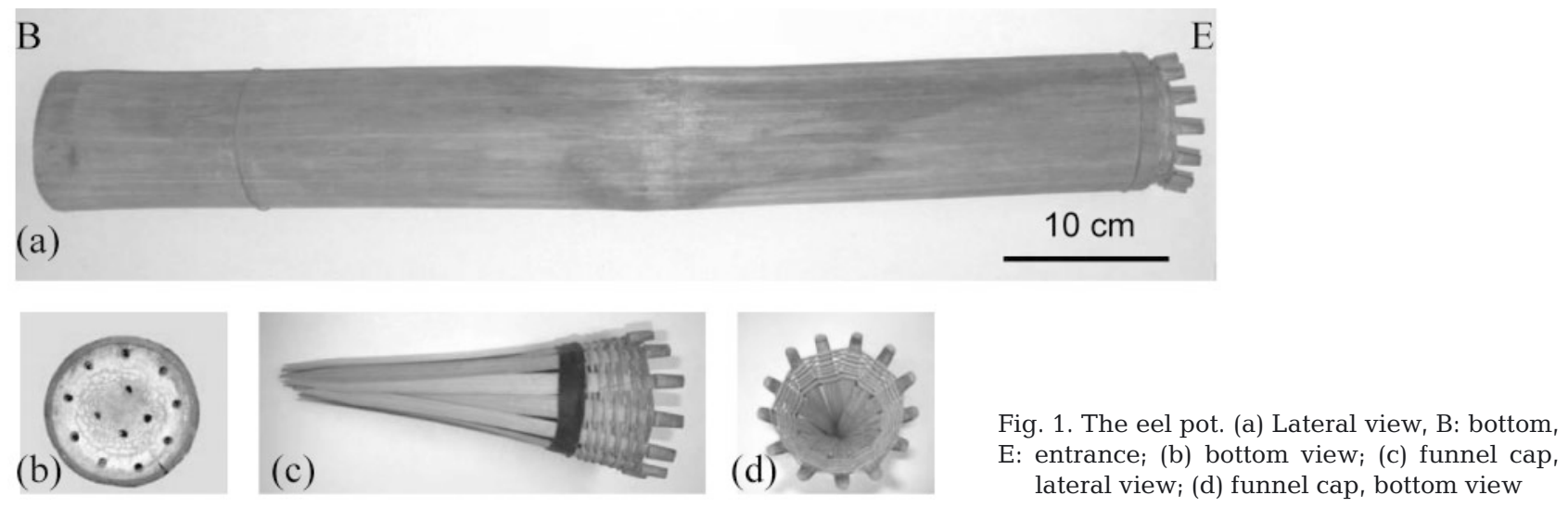




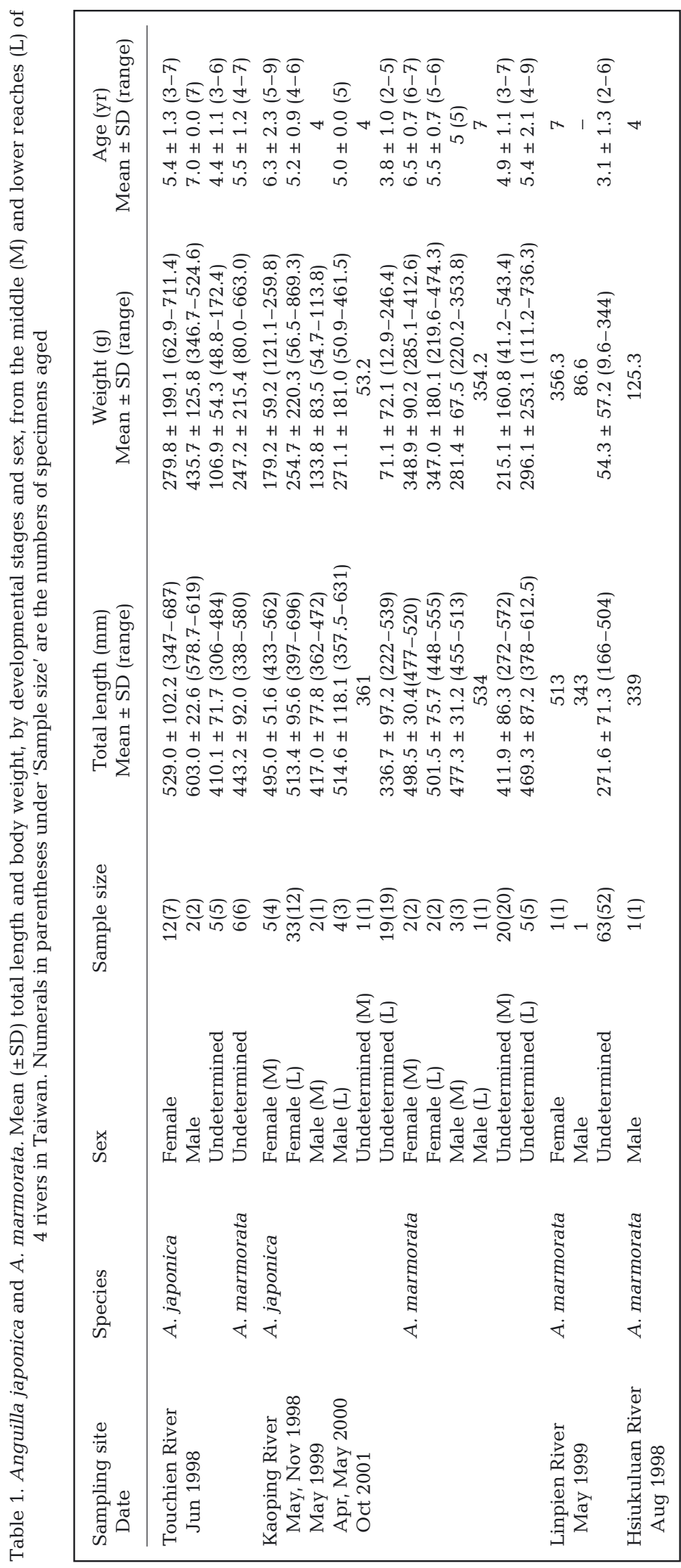

Eels were collected between 1998 and 2001 from the Touchien River, northern Taiwan, the Kaoping and Linpien Rivers in southern Taiwan, and the Hsiukuluan River in eastern Taiwan. A single survey, duration approx. 3 to $5 \mathrm{~d}$, was conducted in each of the Touchien, Linpien, and Hsiukuluan Rivers. In the Kaoping River, 6 surveys were carried out. The eels in the Touchien River were sampled at the head of tidal influence, just downstream of a small dam, and upstream in the middle reach of the river (Fig. 2).

The Kaoping River is the largest river in Taiwan, approx. $171 \mathrm{~km}$ long with a drainage area of $3256 \mathrm{~km}^{2}$. The lower reach (Lin-yuan) of the river is an estuary containing environments from freshwater to brackish water and a salinity range from 0 to $32 \mathrm{ppt}$. The middle reach (Chi-san) of the river is a freshwater environment about $40 \mathrm{~km}$ from the coast.

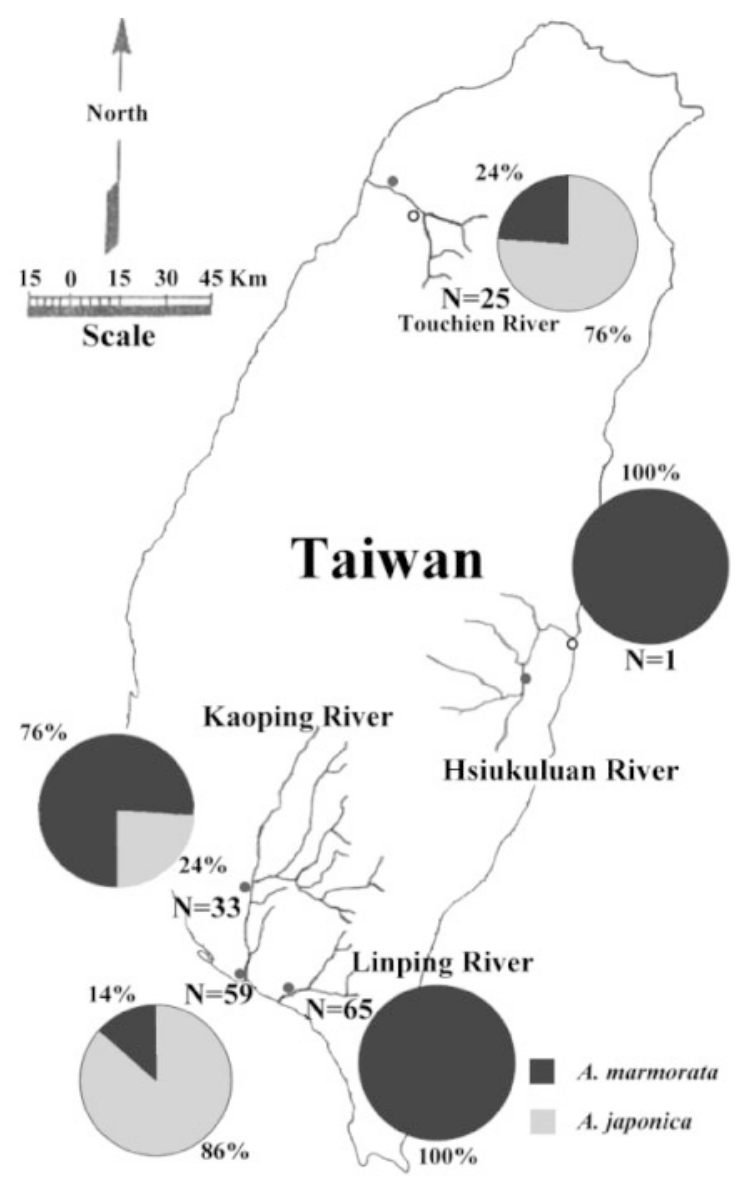

Fig. 2. Anguilla japonica and A. marmorata. Species composition of eels collected in the lower and middle reaches of the 4 rivers. : Sampling site; o: no eel was collected 
Two small agricultural irrigation dams occur in the middle and upper reaches of the river. The annual river discharge of the river was approx. 8455 million $\mathrm{m}^{3}$, with 761 million $\mathrm{m}^{3}$ flowing during the dry season (October to March) and $7694 \mathrm{~m}^{3}$ during the rainy season (April to September).

The Linpien River, $42 \mathrm{~km}$ long, has a drainage area of $344 \mathrm{~km}^{2}$. No water reservoirs or dams occur in this small river except in the upper reach. The sampling site was in freshwater about $6 \mathrm{~km}$ from the coast. The water level at the sampling site was about $50 \mathrm{~cm}$ deep but became almost dry about $5 \mathrm{~km}$ further upstream. The sampling site, although not far from the coast, should be regarded as a middle-reach environment in this short river.

The sampling sites in the middle and lower reach of the Hsiukuluan River are also freshwater environment. The river, $81 \mathrm{~km}$ long, is the largest river in eastern Taiwan and has a drainage area of $1790 \mathrm{~km}^{2}$ that drains into the Pacific Ocean.

Otolith preparation and Sr:Ca analysis. Otoliths were embedded in epofix resin, ground and polished until their primordium was exposed. For electron probe microanalysis, the polished otolith was carboncoated under a high vacuum evaporator. Sr and $\mathrm{Ca}$ concentrations from the primordium to the otolith edge were quantified using an EPMA. A JEOL JXA-8900R system, equipped with wavelength dispersive X-ray spectrometers, was used. Quantitative analyses were conducted using beam conditions of $15 \mathrm{kV}$ for the acceleration voltage, $3 \mathrm{nA}$ for the current, and a $5 \times$ $4 \mu \mathrm{m}$ rectangular scanning beam. The quantitative data were corrected by the ZAF method to calculate oxide compositions (Goldstein et al. 1984), using the standard calibration of calcite $\left(\mathrm{CaCO}_{3}, \mathrm{NMNH} 136321\right)$ and strontiantite $\left(\mathrm{SrCO}_{3}, \mathrm{NMNH} \mathrm{R} 10065\right)$. Sr concentration was measured for $80 \mathrm{~s}$ at $\mathrm{Sr} L \alpha$ peak positions and $20 \mathrm{~s}$ at both the lower and upper sides of the base-

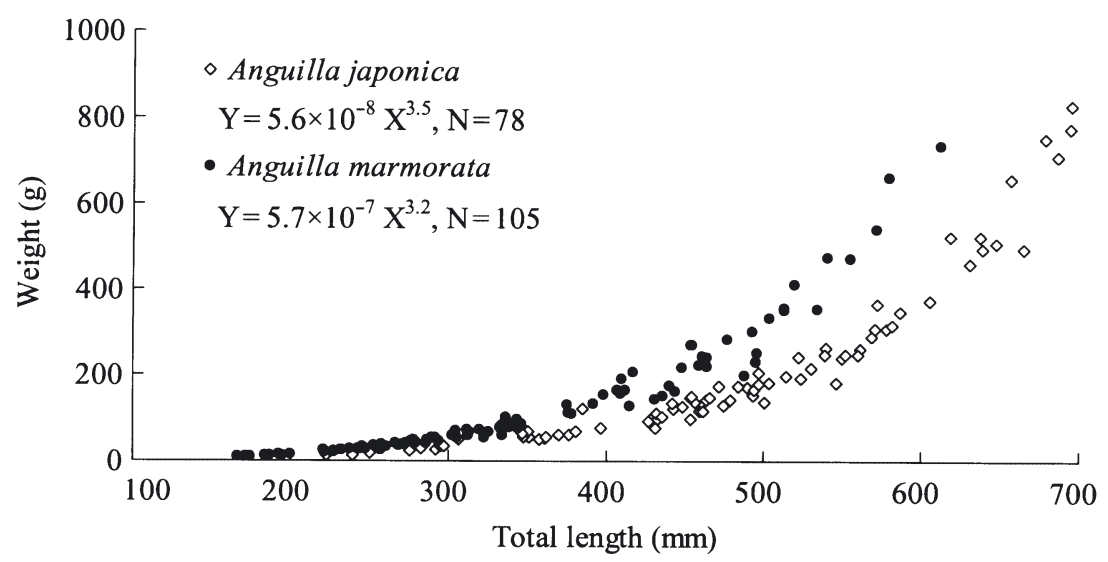

Fig. 3. Anguilla japonica and A. marmorata. Length-weight relationships line. Ca was measured for $20 \mathrm{~s}$ at the $\mathrm{Ca} K \alpha$ peak and for $10 \mathrm{~s}$ at both sides of the baseline. After Sr:Ca ratio analysis, the otolith was polished again to remove the carbon layer and etched for 1 to 2 min with 5\% EDTA to reveal annular marks for age determination. Then, the time spent by the eel in different habitats was determined by examining the temporal trend in the Sr:Ca ratio, relative to their observed value ranges in freshwater, estuarine and marine conditions.

\section{RESULTS}

\section{Species composition of the eels}

The species composition of the eels differed among sampling sites (Fig. 2). In the lower reach of the Touchien River, $76 \%(\mathrm{n}=25)$ of eels were Anguilla japonica and $24 \%$ were $A$. marmorata, while no eels were found in the middle reach of the river. In the lower reach of the Kaoping River, $86 \%(\mathrm{n}=59)$ of eels were $A$. japonica and $14 \%$ were $A$. marmorata. In the middle reach of the Kaoping River, $24 \%(\mathrm{n}=33)$ of eels were $A$. japonica and $76 \%$ were $A$. marmorata. All eels in the lower reach of the Linpien River $(\mathrm{n}=65)$ and the middle reach of the Hsiukuluan River $(\mathrm{n}=1)$ were A. marmorata $(100 \%)$. No eels were caught in the lower reach of the Hsiukuluan River.

\section{Size and relative growth}

Mean $( \pm \mathrm{SD})$ total lengths of the eels from the 4 Taiwanese rivers ranged from 271.6 to $501.5 \mathrm{~mm}$, and weights ranged from 54.3 to $348.9 \mathrm{~g}$ for Anguilla marmorata, and from 336.7 to $603.0 \mathrm{~mm}$ and 71.1 to $435.7 \mathrm{~g}$ for A. japonica (Table 1). The size ranges overlapped between species and rivers. The sexes of 2 to 4 yr old $A$. marmorata from the middle reach of the Kaoping River and lower reach of the Linpien River were mostly undetermined because of gonadal immaturity. The length $(\mathrm{X})$-weight $(\mathrm{Y})$ relationship was $\mathrm{Y}=5.6 \times 10^{-8} \mathrm{X}^{3.5}$ for A. japonica and $\mathrm{Y}=5.7 \times 10^{-7}$ $\mathrm{X}^{3.2}$ for A. marmorata (Fig. 3). The relative growth of length and weight was significantly different between these 2 eel species (analysis of covariance, $F=12.2, \mathrm{p}<$ $0.001, t=3.5, \mathrm{p}<0.001$ for slope, $t=$ 12.5, $\mathrm{p}<0.001$ for intercept). $A$. marmorata was heavier than $A$. japonica at similar lengths. 

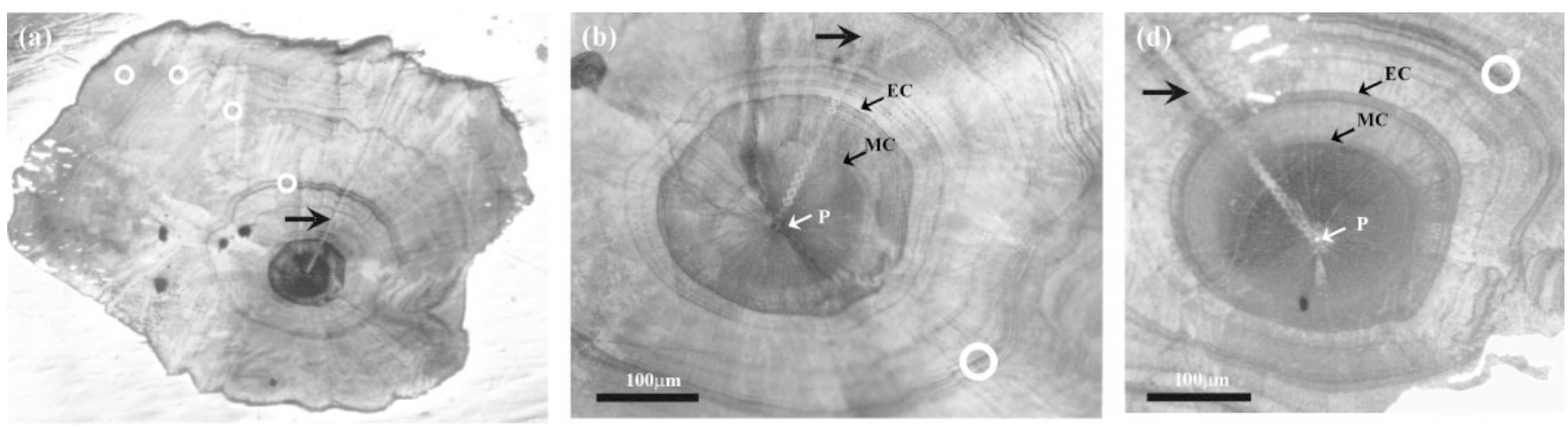

(c)

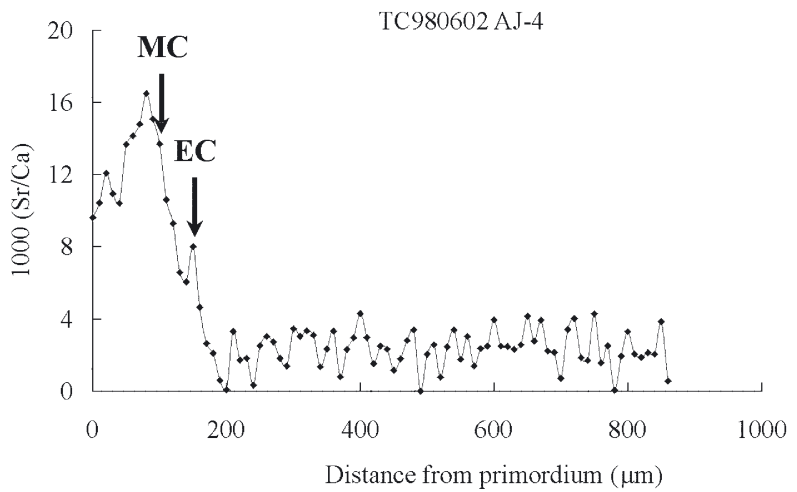

(e)

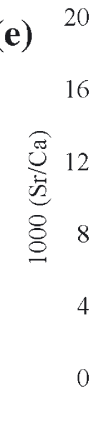

KP011024 AM-1 (D)

Fig. 4. Anguilla japonica and A. marmorata. (a,b,d) Growth checks and (c,e) corresponding changes of Sr:Ca ratios in otoliths of A. japonica (a-c) and A. marmorata (d,e). Panel (b) was magnified from (a). Thick arrows in (a), (b) and (d): spots of Sr:Ca ratio measurements; open circles: annuli; P: primordium; MC: metamorphosis check; EC: elver check

\section{Growth check and corresponding Sr:Ca ratios in otolith before elver stage}

The electron probe created an approx. $1 \mu \mathrm{m}$ deep hole in the sectioned surface of the otolith during the measurement of $\mathrm{Sr}$ :Ca ratios. The position of the hole in combination with the growth check could be used as a time marker to understand the chronological change of the Sr:Ca ratios in otoliths, such as the check of metamorphosis from leptocephalus to glass eel, the check for the elver at estuarine arrival, and the annulus of the adult eel (Fig. 4a,b,d).

The Sr:Ca ratios in the otolith of a selected Anguilla japonica increased from approx. $10 \times 10^{-3}$ in the primordium to a peak of approx. $16 \times 10^{-3}$ at a distance of $110 \mu \mathrm{m}$ from the primordium, which corresponded to the timing between metamorphosis from the leptocephalus to the glass eel stage. The $\mathrm{Sr}: \mathrm{Ca}$ ratios decreased to approx. $7 \times 10^{-3}$ when the glass eel became an elver at estuarine arrival (Fig. 4c). Similar changes in both otolith growth check and $\mathrm{Sr}$ :Ca ratios were also found in A. marmorata (Fig. 4d,e). This indicates that the environmental history of these 2 eels was similar during the marine leptocephalus stage. However, the patterns of the Sr:Ca ratios beyond the elver stage were greatly different between these 2 species (Figs. $5 \& 6$ ).

\section{Sr:Ca ratios in Anguilla japonica otolith}

For the 6 eels collected from the middle reach of the Kaoping River, the otolith $\mathrm{Sr}$ :Ca ratios beyond the elver check were all lower than $4 \times 10^{-3}$, with a highest value of $3.7 \times 10^{-3}$ (Fig. 5a, Table 2). The sampling site of these eels was a purely freshwater environment about $40 \mathrm{~km}$ from the coast and completely free from tidal influence. Thus, eels with otolith $\mathrm{Sr}: \mathrm{Ca}$ ratios lower than $4 \times 10^{-3}$ can be considered to be freshwater residents and eels with Sr:Ca ratios larger than $4 \times 10^{-3}$ can be regarded as estuarine or marine residents. Based on these criteria, the environmental history of Anguilla japonica beyond the elver stage was classified into 3 different migratory contingents:

Type 1 (freshwater contingent): all Sr:Ca ratios from elver mark to the edge of otolith were less than $4 \times$ $10^{-3}$. All eels from the middle reach of the river were Type 1, as were $14 \%$ of the eels from the lower reach of the Kaoping River (Table 2). The mean $( \pm \mathrm{SD}) \mathrm{Sr}$ :Ca ratios in otoliths of Type 1 eels in the middle reach 

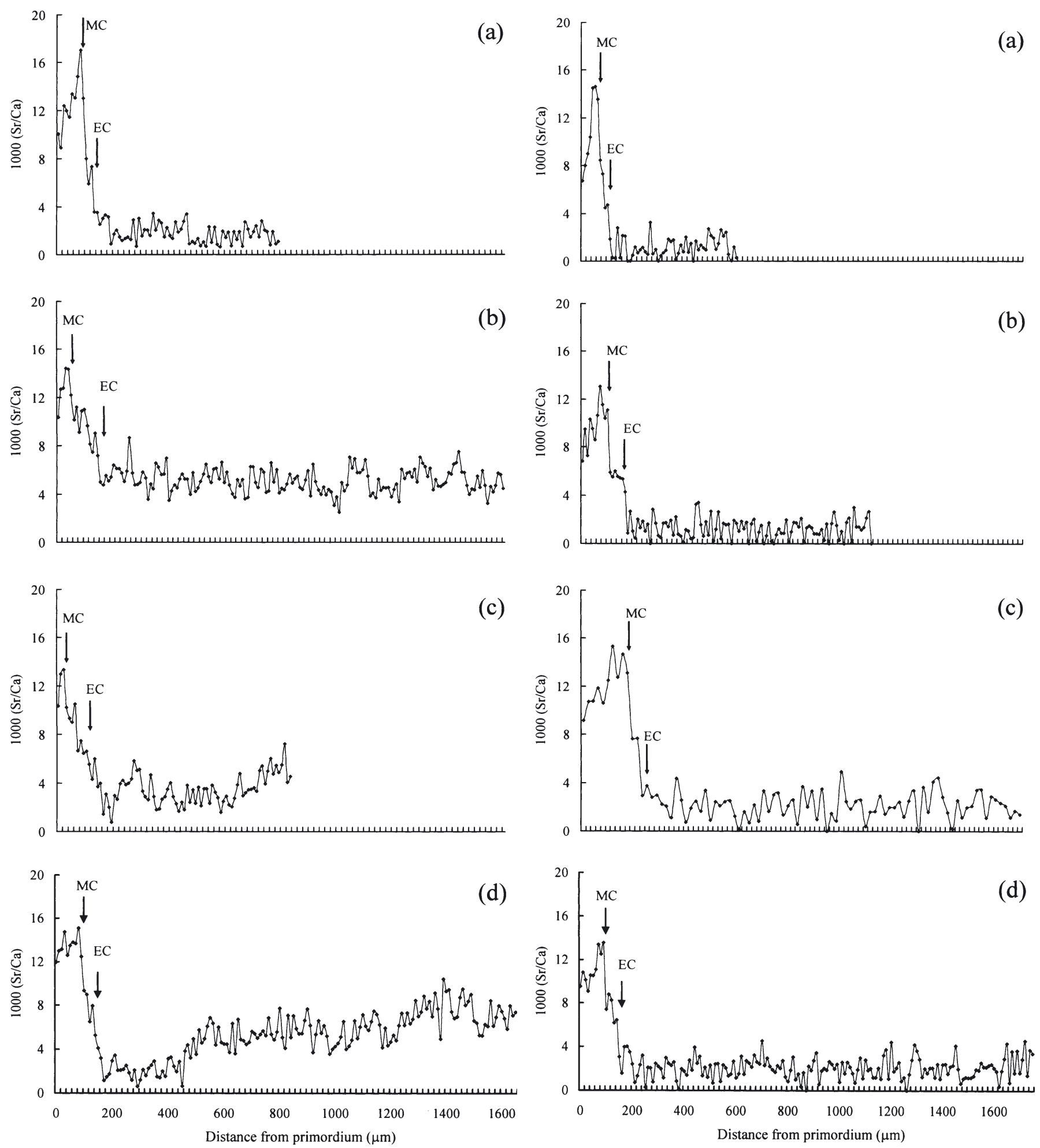

Fig. 5. Anguilla japonica. Temporal changes in the $\mathrm{Sr}: \mathrm{Ca}$ ratios of otoliths of different migratory contingents, collected from the middle and lower reaches of the Kaoping River. (a) Type 1 (freshwater), (b) Type 2 (seawater), (c,d) Types 3a and $3 \mathrm{~b}$ (estuarine). EC: elver check, MC: metamorphosis check. Panel (a): $41.8 \mathrm{~cm}$ yellow eel, (b): $63.5 \mathrm{~cm}$ silver eel, (c): $45.1 \mathrm{~cm}$ silver eel, (d): $59.3 \mathrm{~cm}$ silver eel

Fig. 6. Anguilla marmorata. Temporal changes in the Sr:Ca ratios of otoliths of different migratory contingents collected from the lower reach of the Linpien River. $(a, b)$ Type 1 (freshwater), (c,d) Type 3a (estuarine). Panel (a): $22.1 \mathrm{~cm}$ yellow eel; (b): $32.5 \mathrm{~cm}$ yellow eel; $(\mathrm{c}): 43.1 \mathrm{~cm}$ yellow eel (d): $62.3 \mathrm{~cm}$ silver eel 


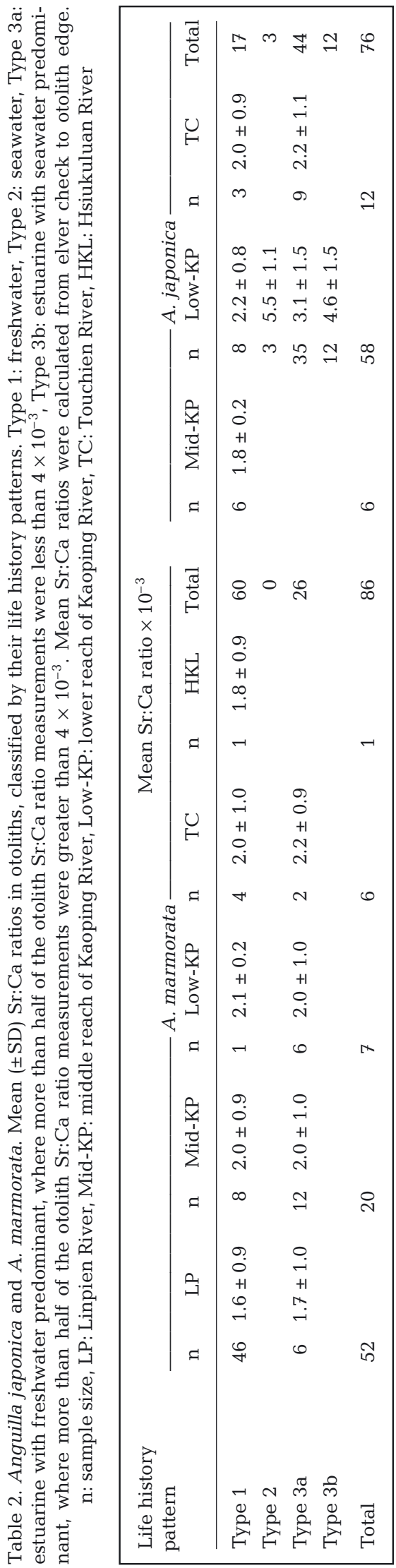

$\left(1.8 \pm 0.2 \times 10^{-3}\right.$, range: 0.0 to $\left.3.7 \times 10^{-3}\right)$ were very close to those in the lower reach of the Kaoping River $\left(2.2 \pm 0.8 \times 10^{-3}\right.$, range: 0.0 to $\left.4.5 \times 10^{-3}\right)$ (Table 2$)$. Three Anguilla japonica (25\%) from the Touchien River were also Type 1, with a mean Sr:Ca ratio of $1.98 \pm 0.9 \times 10^{-3}$, which was also very close to that of the Type 1 eels from the Kaoping River (Table 2).

Type 2 (seawater contingent): of the 58 eels collected in the lower reach of the Kaoping River, 3 (5\%) were Type 2 . The mean $\mathrm{Sr}$ :Ca ratio in the otoliths of Type 2 eels beyond the elver stage was $5.5 \pm 1.1 \times 10^{-3}$ (range 2.5 to $8.8 \times 10^{-3}$ ) (Table 2). The higher and varied $\mathrm{Sr}: \mathrm{Ca}$ ratios in the otoliths of Type 2 eels indicated that they seasonally migrated to high-salinity seawater during their stay in the lower reach (Fig. 5b).

Type 3 (estuarine contingent): of the 58 eels collected from the lower reach of the Kaoping River, 47 (81\%) were Type 3 (Table 2). After the elver stage, the mean Sr:Ca ratios in the otoliths of Type 3 eels varied considerably among individuals. Type 3 eels did not have consistently low or high $\mathrm{Sr}$ :Ca ratios as did those of Types 1 and 2. Type 3 eels illustrated a variety of temporal patterns in the Sr:Ca ratios of their otoliths (Fig. $5 \mathrm{c}, \mathrm{d}$ ). Type 3 eels were further divided into 2 subtypes, according to the duration of their estuarine residence, which varied from several months to years. Type 3a (freshwater-favoring contingent) had $\mathrm{Sr}$ :Ca ratios less than $4 \times 10^{-3}$ over more than half of their life span, while Type $3 \mathrm{~b}$ (seawater-favoring contingent) had Sr:Ca ratios greater than $4 \times 10^{-3}$ over more than half of their life span. Type 3 a eels were approx. 3 times more abundant than Type $3 \mathrm{~b}$, indicating that this species preferred freshwater when they migrated into the estuary (Table 2). In the Touchien River, $75 \%$ of Anguilla japonica (9 eels) were Type 3a, with a mean $\mathrm{Sr}$ :Ca ratio of $2.2 \pm 1.1 \times 10^{-3}$.

\section{Sr:Ca ratios in Anguilla marmorata otolith}

The mean Sr:Ca ratios in Type 1 Anguilla marmorata otoliths were similar to those of Type 1 A. japonica (Table 2). No Type 2 or $3 \mathrm{~b}$ eels were found for $A$. marmorata. The pattern of Sr:Ca ratios in otoliths of $A$. marmorata of Type 3a (Fig. 6c,d) was more similar to that for Type 1 (Fig. 6a,b) than for Type 3a of A. japonica (Fig. 5c). The A. marmorata of Type 3a had few spots with $\mathrm{Sr}: \mathrm{Ca}$ ratios higher than $4 \times 10^{-3}$, indicating that $A$. marmorata did not frequently inhabit a highly saline environment.

In the Linpien River, 46 Anguilla marmorata were Type $1(88 \%)$ and 6 were Type $3 a(12 \%)$. The mean otolith $\mathrm{Sr}$ :Ca ratios of Type $1\left(1.6 \pm 0.9 \times 10^{-3}\right)$ and Type 3a $\left(1.7 \pm 1.0 \times 10^{-3}\right)$ eels were similar (Table 2$)$. In the middle reach of the Kaoping River, of 20 eels, 8 (40\%) were Type 1 and 12 (60\%) were Type 3a, with mean 
$\mathrm{Sr}$ :Ca ratios of $2.0 \pm 0.9 \times 10^{-3}$ and $2.0 \pm 1.0 \times 10^{-3}$, respectively (Table 2 ). In the lower reach of the Kaoping River, of 7 eels, 1 was Type $1(14 \%)$ and 6 (86\%) were Type $3 \mathrm{a}$, with mean Sr:Ca ratios of $2.1 \pm 0.2 \times 10^{-3}$ and $2.0 \pm 1.0 \times 10^{-3}$, respectively (Table 2 ). The mean otolith Sr:Ca ratios were not significantly different between Types 1 and 3a eels, whether they were from the middle or lower reach of the Kaoping River (2-way ANOVA, $p=0.83$ for Types 1 and $3 a, p=0.38$ for middle and lower reaches, and $\mathrm{p}=0.19$ for interaction). In the Touchien River, 4 eels were Type 1 (67\%) and 2 eels $(33 \%)$ were Type $3 a$, with mean $\mathrm{Sr}$ :Ca ratios of $2.0 \pm 1.0 \times 10^{-3}$ and $2.2 \pm 0.9 \times 10^{-3}$, respectively (Table 2). The only A. marmorata caught in the Hsiukuluan River was also Type 1, with a mean otolith $\mathrm{Sr}$ :Ca ratio of $1.8 \pm 0.9 \times 10^{-3}$. Of the total 86 eels, 60 individuals $(70 \%)$ were of the completely freshwater contingent (Type 1) and 26 individuals (30\%) resided in brackish water for a short period (Type 3a, Table 2). This indicates that $A$. marmorata is a freshwater-oriented species in the growth phase (yellow eel stage).

\section{DISCUSSION}

\section{Habitat segregation}

The difference in percentage composition of Anguilla japonica and A. marmorata between middle and lower reaches of the Kaoping River (Fig. 2) indicated that $A$. marmorata tended to reside in the upper reach while A. japonica tended to reside in the lower reach of the river. In contrast, all of the 65 eels caught in the lower reach of the Linpien River approx. $6 \mathrm{~km}$ from the river mouth were $A$. marmorata, and no A. japonica were found. Although the lower reach of the Linpien River was not far from the coast, it was free from the influence of tidal flux. The sampling site in the Linpien River, which consisted of shallow water and fast current, was more similar to a middle reach than to a lower reach. Thus, this environment was not attractive to A. japonica but was attractive to A. marmorata, which became dominant in the lower reach of the Linpien River. Most (88\%) of the 65 eels from the Linpien River were of the freshwater type (Table 2). This also supported the hypothesis of a geographic separation in the distribution of these 2 species within the river.

Anguilla marmorata and A. japonica also differed in microhabitat preferences. A. marmorata preferred deep pools in the river, whereas A. japonica preferred sandy and muddy substrates with shelters. Eels of different size also differed in habitat preference. The larger eels tended to reside in deep pools in the upper reach, but small eels chose shallow waters in the lower reach of the river. The deep pool in the middle reach of the
Kaoping River was approximately $2 \mathrm{~m}$ deep, which was suitable for adult A. marmorata. The upper reach of the Linpien River was not suitable, however, because it became too shallow during the dry winter season. The drought conditions commonly found in the steep and short rivers of Taiwan may negatively influence the migratory behavior and habitat use of the eel by confining it to isolated, deep pools and interrupting their movement between pools.

\section{Different migratory behavior}

Anguilla japonica has a more phenotypic plasticity than A. marmorata, and can be classified into freshwater, seawater and estuarine contingents (Table 2, Fig. 5). Approx. $80 \%$ of A. japonica in the lower reach of the Kaoping River were estuarine-oriented, as was noted by Tzeng et al. (2002, 2003). In contrast, A. marmorata was mainly freshwater-oriented and apparently avoided residence in a brackish water environment, as inferred from the few Sr:Ca ratios higher than $4 \times 10^{-3}$ in the otoliths of the Type 3 eels (Table 2, Fig 6c,d). One possible explanation for this difference in migratory behavior and habitat use between species is that the brackish water habitat was overwhelmingly dominated by A. japonica. Consequently, no surplus estuarine habitats were available for A. marmorata. Therefore, A. marmorata was expelled to the upper reaches, where the habitats were less productive and unstable. In contrast, if $A$. marmorata occupies fresh water habitats in the middle and upper reaches of rivers, A. japonica would be expelled to the lower reach.

These 2 eel species may have coped with interspecific resource competition by allopatric rather than sympatric distribution (Fig. 2). Interspecific competition possibly plays an important role in the distribution of the 2 eel species in the river. Migrating to the upper river takes greater risk and costs more energy than residing in estuary and the lower river. If no interspecific interaction exists, it seems difficult to explain the geographic separation of the 2 eel species in the river. Environmental factors as well as the interspecific interactions might influence the habitat choice of fish. The specific differences in habitat choice should be carefully interpreted because the difference might not be a simple interaction among competitors (Helfman et al. 1997). A species occurs where it does because the fish functions best there, i.e. the choice of habitat reflects the use of physiologically optimal environments rather than being the result of interactions with other species over limiting resources. If this is what governs the habitat choice of Anguilla japonica and A. marmorata, brackish waters may be the optimal environment for $A$. japonica and freshwater for $A$. marmorata. Chloride cells in the gill epithelium of 
A. japonica markedly increased during their first week after transfer from freshwater to seawater (Shirai \& Utida 1970). When the seawater adapted eel was transferred to freshwater, their chloride cells degenerated slowly over the following $10 \mathrm{wk}$. The ability of chloride cells to develop quickly is essential for euryhaline fish such as $A$. japonica, to maintain a constant osmolality under variable salinity environments such as the estuary. No study on the salinity tolerance of $A$. marmorata has yet been conducted, and we do not know if it can adapt to large changes in salinity during the yellow stage. If it can, it should have evolved a phenotypic behavior similar to that of A. japonica, and may then be expected to compete for the same resources. However, A. marmorata does not have as many migratory contingent types as $A$. japonica.

\section{A hypothesis of adaptive radiation}

To date, 3 temperate eels, Anguilla anguilla, A. rostrata and $A$. japonica, have been found to have flexible migratory patterns, including freshwater, seawater and estuarine contingents (Tzeng et al. 2000b, 2002, 2003, Tsukamoto \& Arai 2001, Jessop et al. 2002). Whether the other 2 temperate eels $A$. australis and $A$. dieffenbachii have similar behavior is not clear. $A$. dieffenhachii and $A$. australis are usually found in the brackish estuaries of New Zealand (Jellyman et al. 1997) and numerous $A$. australis reside in a salty inland lake in South Australia (L. McKinnon pers. comm.). A. australis and A. dieffenbachii yellow eels are evidently able to regulate the plasma osmolality in hyper-saline environments. Thus, they are likely to have different migratory contingents.

Temperate eels are believed to have evolved from tropical eels (Ege 1939, Aoyama et al. 1996, Aoyama et al. 2001, Lin et al. 2001). If the tropical species, such as A. marmorata, conserved the freshwater preference in the growth phase, the temperate species have to adapt to seawater to find vacant niches, and this may have led them to develop diversified migratory contingents. The salinity choice by the congeners of the eel may be regarded as 'character displacement' similar to that for other species for adaptive radiation (Brown \& Wilson 1956, Schluter 1994, 2000). Estuarine and coastal waters have higher productivity than freshwater rivers in the temperate zone, while freshwater rivers have higher productivity than seawater in the tropical zone (Gross 1987). Occupation of the lower reach of rivers and coastal waters in the temperate area could have optimal evolutionary fitness for temperate eels such as $A$. japonica. The tropical eel A. marmorata is an ancient species of the freshwater eel that seems to have a more conservative, freshwater-oriented migratory life cycle in which they migrate upstream to expand their habitat. But in subtropical Taiwan, where the temperate and tropical species coexist, the most productive lower reach of the river would be best for both species groups. Since these 2 eel species are apparently geographically segregated in distribution, productivity of the river seems not to be the only or determinant factor in eel distribution, especially when similar species coexist in the same river. Otherwise, A. marmorata would be as abundant as A. japonica in the estuary and lower reach, where the productivity is generally higher than in the upper reach of the river. A disparity in habitat preferences reflects the biological differences between the species, such as growth, feeding preferences, and preferences for water temperature, depth and bottom type. A. marmorata may simply out-compete $A$. japonica in the habitat typical of the upper reaches of freshwater streams, and conversely A. japonica may out-compete A. marmorata in the lower reaches and estuary, forcing them upstream. Competition combined with 'evolutionarily developed preferences' seems a more plausible explanation for the geographic segregation in A. japonica and $A$. marmorata distribution.

Acknowledgements. This study was conducted with financial support from the National Science Council (contract no. NSC91-2313-B002-291, awarded to W.N.T.). We thank Mr. G. H. Cheng for otolith preparation, Mr. B. M. Jessop, and the anonymous reviewers for their helpful comments on an early draft of the paper.

\section{LITERATURE CITED}

Aoyama J, Kobayashi T, Tsukamoto K (1996) Phylogeny of eels suggested by mitochondrial DNA sequences. Nippon Suisan Gakkaishi 62:370-375

Aoyama J, Mutsumi N, Tsukamoto K (2001) Molecular phylogeny and evolution of the fresh water eel, genus Anguilla. Mol Phylogenet Evol 20:450-459

Arai T, Otake T, Tsukamoto K (1997) Drastic changes in otolith microstructure and microchemistry accompanying the onset of metamorphosis in the Japanese eel Anguilla japonica. Mar Ecol Prog Ser 161:17-22

Arai T, Limbong D, Otake T, Tsukamoto K (1999) Metamorphosis and inshore migration of tropical eels, Anguilla spp., in the Indo-Pacific. Mar Ecol Prog Ser 182:283-293

Arai T, Marui M, Miller MJ, Tsukamoto K (2002a) Growth history and inshore migration of the tropical eel, Anguilla marmorata, in the Pacific. Mar Biol 140(2):309-316

Arai T, Marui M, Otake T, Tsukamoto K (2002b) Inshore migration of a tropical eel, Anguilla marmorata, from Taiwanese and Japanese coasts. Fish Sci 68(1):152-157

Brown WL Jr, Wilson EO (1956) Character displacement. Syst Zool 5:46-64

Budimawan (1997) The early life history of the tropical eel Anguilla marmorata (Quoy \& Gaimard, 1824) from 4 Pacific estuaries, as revealed from otolith microstructural analysis. J Appl Ichthyol 13:57-62

Campana (1999) Chemistry and composition of fish otoliths: pathways, mechanism and applications. Mar Ecol Prog Ser 188:263-297 
Cheng PW, Tzeng WN (1996) Timing of metamorphosis and estuarine arrival across the dispersal range of the Japanese eel Anguilla japonica. Mar Ecol Prog Ser 131:87-96

Ege V (1939) A revision of the genus Anguilla Shaw: a systematic, phylogenetic and geographical study. Dana Rep 16:1-256

Goldstein JI, Newbury DE, Echlin P, Joy DC, Fiori C, Lifshin E (1984) Scanning electron microscopy and x-ray microanalysis - a text for biologists, materials scientists, and geologists. Plenum Press, New York

Gross MR (1987) Evolution of diadromy in fishes. In: Dadswell MJ, Klauda RJ, Moffitt CM, Saunders RL, Rulifson RA, Cooper JE (eds) Common strategies of anadromous and catadromous fishes. Am Fish Soc Symp 1, Bethesda, MD, p 14-25

Han YS, Chang CW, He JT, Tzeng WN (2001) Validation of the occurrence of short-finned eel Anguilla bicolor pacifica in natural waters of Taiwan. Acta Zool Taiwanica 12: 9-19

Helfman GS, Collette BB, Facey DE (1997) The diversity of fishes. Blackwell Science, Oxford

Jellyman DJ, Glova GJ, Sagar PM, Sykes JR (1997) Spatiotemporal distribution of fish in the Kakanui River estuary, South Island, New Zealand. NZ J Mar Freshw Res 31: 103-118

Jessop BM, Shiao JC, Iizuki Y, Tzeng WN (2002) Migratory behaviour and habitat use by American eels Anguilla rostrata as revealed by otolith microchemistry. Mar Ecol Prog Ser 233:217-229

Kawakami Y, Mochioka N, Morishita K, Toh H, Nakazono A (1998) Determination of the fresh water mark in otoliths of Japanese eel elvers using microstructure and Sr:Ca ratios. Environ Biol Fish 53:421-427

Lin YS, Poh YP, Tzeng CS (2001) A phylogeny of fresh water eels inferred from mitochondrial genes. Mol Phylogenet Evol 20:252-261

Miller MJ, Tsukamoto K (2001) Evidence of a spawning area of Anguilla marmorata in the North Equatorial Current of the western North Kaciric. J Taiwan Fish Res 9(1\&2): 191-198

Otake T, Ishii T, Nakahara M, Nakamura R (1994) Drastic changes in otolith strontium:calcium ratios in leptocephali and glass eels of Japanese eel Anguilla japonica. Mar Ecol Prog Ser 112:189-193

Pannella G (1971) Fish otolith: daily growth layers and periodical patterns. Science 173:1124-1127

Payan P, Edeyer A, De Pontual H, Borelli G, Boeuf G, MayerGostan N (1999) Chemical composition of saccular endolymph and otolith in fish inner ear: lack of spatial uniformity. Am J Physiol 277 46:123-131

Radtke RL, Kinize III RA, Folsom SD (1988) Age at recruitment of Hawaiian freshwater gobies. Environ Biol Fish 23: 205-213

Radtke RL, Townsend DW, Folsom SD, Morrison MA (1990) Strontium:calcium concentration ratios in otoliths of herring larvae as indicators of environmental histories. Environ Biol Fish 27:51-61

Schluter D (1994) Experimental evidence that competition promotes divergence in radiation. Science 266:298-801

Schluter D (2000) Ecological character displacement in adaptive radiation. Am Nat 156:4-16

Shirai N, Utida S (1970) Development and degeneration of the chloride cell during seawater andfresh water adaptation of the Japanese eel, Anguilla japonica. Z Zellforsch 103: $247-264$

Tesch FW (1977) The eel-biology and management of Anguilla eel. Chapman \& Hall, London

Editorial responsibility: Otto Kinne (Editor),

Oldendorf/Luhe, Germany
Tsukamoto K (1992) Discovery of the spawning area for Japanese eel. Nature 356:789-791

Tsukamoto K, Arai T (2001) Facultative catadromy of the eel Anguilla japonica between freshwater and seawater habitats. Mar Ecol Prog Ser 220:265-276

Tsukamoto K, Nakai I, Tesch WV (1998) Do all freshwater eels migrate? Nature 396:635-636

Tzeng WN (1982) New record of the elver of Anguilla celebesensis Kaup from Taiwan. Bioscience 19:57-66

Tzeng WN (1983) Species identification and commercial catch of the Anguillid elvers from Taiwan. China Fish Mon 366:16-23

Tzeng WN (1990) Relationship between growth rate and age at recruitment of Anguilla japonica elvers in a Taiwan estuary as inferred from otolith growth increments. Mar Biol 107:75-81

Tzeng WN (1996a) Effects of salinity and ontogenetic movements on strontium:calcium ratios in the otoliths of the Japanese eel, Anguilla japonica Temminck \& Schlegel. J Exp Mar Biol Ecol 199:111-122

Tzeng WN (1996b) Short- and long-term fluctuations in catches of elvers of the Japanese eel, Anguilla japonica, in Taiwan. In: Hancock DA, Smith DC, Grant A, Beumer JP (eds) Developing and sustaining world fisheries resources - the state of science and management world fisheries congress. CSIRO Publishing, Collingwood, p 85-89

Tzeng WN (2003) The processes of onshore migration of Japanese eel Anguilla japonica as revealed by otolith microstructure. In: Aida $\mathrm{K}$, Tsukamoto $\mathrm{K}$, Yamauchi $\mathrm{K}$ (eds) Advances in eel biology. Springer-Verlag, Tokyo, p 181-190

Tzeng WN, Tabeta O (1983) First record of the short-finned eel Anguilla bicolor pacifica from Taiwan. Bull Jpn Soc Sci Fish 49:27-32

Tzeng WN, Tsai YC (1994) Changes in otolith microchemistry of the Japanese eel, Anguilla japonica, during its migration from the ocean to the rivers of Taiwan. J Fish Biol 45: 671-683

Tzeng WN, Cheng PW, Lin FY (1994) Relative abundance, sex ratio and population structure of the Japanese eel Anguilla japonica in the Taushui River System of northern Taiwan. J Fish Biol 46:183-201

Tzeng WN, Hsiao JJ, Shen HP, Chern YT, Wang YT, Wu JY (1995) Feeding habit of the Japanese eel Anguilla japonica in the streams of northern Taiwan. J Fish Soc Taiwan 22:279-302

Tzeng WN, Severin KP, Wickström H (1997) Use of otolith microchemistry to investigate the environmental history of European eel Anguilla anguilla. Mar Ecol Prog Ser 149: $73-81$

Tzeng WN, Wang CH, Wickström H, Reizenstein M (2000a) Occurrence of the semi-catadromous European eel Anguilla anguilla (L.) in Baltic Sea. Mar Biol 137:93-98

Tzeng WN, Lin HR, Wang CH, Xu SN (2000b) Differences in size and growth rates of male and female migrating Japanese eels in Pearl River, China. J Fish Biol 57: $1245-1253$

Tzeng WN, Shiao JC, Iizuka Y (2002) The use of otolith Sr:Ca ratios to study the riverine migratory behaviours of Japanese eel Anguilla japonica. Mar Ecol Prog Ser 245:213-221

Tzeng WN, Iizuka Y, Shiao JC, Yamada Y, Oka HP (2003) Identification and growth rates comparison of divergent migratory contingents of Japanese eel (Anguilla japonica). Aquaculture 216:77-86

Williamson GR (1993) The eels Anguilla marmorata and A. japonica in the Pearl River, China, and Hong Kong. Asian Fish Sci 6:129-138

Submitted: January 13, 2003; Accepted: June 14, 2003

Proofs received from author(s): October 6, 2003 